\title{
Blood Vessel Endothelium
}

National Cancer Institute

\section{Source}

National Cancer Institute. Blood Vessel Endothelium. NCI Thesaurus. Code C53395.

The layer of cells that line the lumen of a blood vessel. 